\title{
Volatile compounds in off-odor honey
}

\section{Bruno Rafael da Silva' ${ }^{1}$ (D) Carlos D'Apolito ${ }^{2}$ (i) Sílvia Carvalho Campos Botelho ${ }^{10}$ Larissa Cavalheiro ${ }^{3}$ (i) Ednaldo Antônio de Andrade ${ }^{3}$ (i) Carmen Wobeto $^{3^{*}}$ (iD}

\author{
${ }^{1}$ Empresa Brasileira de Pesquisa Agropecuária (Embrapa), Embrapa Agrossilvipastoril. Sinop, MT, Brasil. \\ ${ }^{2}$ Faculdade de Geociências (FAGEO), Universidade Federal de Mato Grosso (UFMT), Cuiabá, MT, Brasil. \\ ${ }^{3}$ Instituto de Ciências Naturais, Humanas e Sociais, Universidade Federal de Mato Grosso (UFMT), 78550-728, Sinop, MT, Brasil. E-mail: \\ carmenwobeto2014@gmail.com. "Corresponding author.
}

ABSTRACT: Climatic conditions in the mid-northern region of Mato Grosso State in Brazil are favorable for beekeeping. However, since 2011, the honey production chain has suffered losses because the production of off-odor honey has made it impossible to market the honey. Reports from beekeepers indicated a relationship between the off-odor in the honey and the nectar of Borreria verticillata (L.) G. Mey (Rubiaceae). In this study, the botanical origins and volatile profiles of ten off-odor honeys (H1-H10) and flowers of B. verticillata were evaluated. Palynological and sensorial analyses of the honeys were performed; a scale from 1 to 4 was applied for the sensorial analysis, in which 1 indicates no off-odor and 4 indicates extreme off-odor. Analysis of volatile was performed by using headspace solid-phase microextraction and gas chromatography-mass spectroscopy methods. The honeys investigated were classified with very high to intense off-odors, except H4 and H5, which did not differ from the control honey (no off-odor). Palynological analyses showed that honeys H1-H4, H7, and H9 were monofloral from $\mathrm{B}$. verticillata, whereas in $\mathrm{H5}, \mathrm{H6}, \mathrm{H8}$, and $\mathrm{H} 10$ this pollen were accessory. However, there was no quantitative correlation between the B. verticillata pollen content and the off-odor attributes of the honeys. Skatole was identified in all of the honeys except H4, H5, and the control honeys, suggesting that skatole contributed to the off-odor attributes of the products. However, further studies are required to investigate the origin of the skatole because it is not transferred directly from B. verticillata flowers to the honey.

Key words: Apis mellifera, melissopalynology, gas chromatography, headspace solid-phase microextraction.

Compostos voláteis em mel com odor indesejável

RESUMO: As condições climáticas da região Centro-Norte do Estado de Mato Grosso são favoráveis a apicultura, contudo ocorrem prejuízos nesta cadeia produtiva desde 2011 devido a produção de mel com odor indesejável, o que impossibilitou sua comercialização. Relatos dos apicultores apontaram relação da ocorrência do odor indesejável no mel com o néctar Borreria verticillata (L.) G. Mey (Rubiaceae). Neste estudo foi avaliado a origem botânica e o perfil de voláteis de méis (M1 até M10) com odor indesejável e das flores de B. verticillata. Foi realizada a análise polínica do mel e também sensorial, empregando-se uma escala de um a quatro pontos, em que um refere-se a nenhum odor desagradável e quatro, extremo odor desagradável. A análise de compostos voláteis no mel e nas flores de B. verticillata foi realizada utilizando microextração em fase sólida por headspace e cromatografia gasosa acoplada a detector por espectrometria de massas. Os méis investigados foram classificados desde muito a extremo odor desagradável, exceto os méis M4 e M5, que não diferiram do mel controle (sem odor indesejável). Os méis M1 até M4, M7 e M9 eram monoflorais de B. verticillata, enquanto M5, M6, M8 e M10 o pólen B. verticillata era acessório. Todavia, não foi observada correlação quantitativa entre o teor deste pólen e o atributo odor indesejável. O escatol foi identificado nos méis investigados, exceto em M4, M5 e mel controle. Estes resultados sugerem que o escatol contribuiu para o atributo odor desagradável do produto. Contudo, mais estudos devem ser conduzidos para investigar a origem do odor indesejável, porque o escatol não foi transferido diretamente das flores para o mel.

Palavras-chave: Apis mellifera, melissopalinologia, cromatografia gasosa, microextração de fase sólida por headspace.

\section{INTRODUCTION}

The mid-northern region of Mato Grosso State in Brazil, a transition region between the Amazon rainforest and the "cerrado" (savannah), offers appropriate factors for successful apiculture, i.e., favorable climatic conditions, botanical variety, and the presence of Africanized bees (IMEA, 2017). However, since 2011, the honey production chain has suffered economic losses because some honey 
produced has had an off-odor, which has hampered its marketing (IBGE, 2010, 2011, 2012).

Empirical observations of beekeepers indicated a relationship between the nectar of an herbaceous plant known as "vassourinha" (Borreria verticillata (L.) G. Mey (Rubiaceae) and the occurrence of undesirable odor in the honey, because the relocation of apiaries to regions without this plant was an efficient method to avoid or reduce the unwanted odor. However, the spread of this invasive species and the economic viability of relocating hives are problems still faced by this production sector.

Honey aroma compounds are derived from the transfer of volatile substances from plants, metabolic transformations of plant constituents by bees, the metabolism of bees, changes that occur during honey processing, and the action of microorganisms (NAEF et al, 2004; BARONI et al., 2006; RIBEIRO et al., 2008; DE-MELO et al., 2018).

Volatile-profile studies have identified chemical markers in monofloral honeys (BARONI et al., 2006; SEISONEN et al., 2015). Changes in volatiles have been reported in honeys subjected to heating, with a consequent alteration of flavor, intensifying the bitter and roasted tastes, and development of the appearance and taste of medicine (CASTRO-VÁZQUEZ et al., 2012; RIBEIRO et al., 2012). KRUŽÍ et al. (2017) reported a methodology for investigating volatile compounds in honeys to evaluate the quality and the occurrence of adulterations.

However, there are no scientific reports of undesirable volatiles in fresh honeys. This study evaluated the botanical origin and the volatile profiles of off-odor honeys produced in the mid-northern region of Mato Grosso State, Brazil.

\section{MATERIALS AND METHODS}

Ten samples (H1-H10) reported by beekeepers as off-odor honeys were collected, in three replicates of each, from apiaries in different cities of the mid-northern region of Mato Grosso State: Nova Ubiratã, Sinop, Tabaporã, Santa Carmen, and Ipiranga do Norte. Honeys H1 and H2 were from the 2015 harvest, H3 from 2016, H4 and H5 from 2017, and H6-H10 from 2018 (Table 1). Honeys H1$\mathrm{H} 3$ were collected in honeycombs and transported in thermal boxes to the Food Technology Laboratory of the Federal University of Mato Grosso (UFMT), Campus of Sinop, where the honeys were extracted from the combs. Samples H4-H10 were centrifuged and delivered to this laboratory by beekeepers. The honeys were stored in a refrigerator until the palynological, sensorial, and volatile-compound analyses were performed.

In June 2015, samples of the plant known as "vassourinha" (Borreria verticillata (L.) G. Mey) were collected in three replicates and sent to the Biological Collection of the Southern Amazon (ABAM), UFMT, in Sinop, for botanical identification. A voucher specimen was deposited at ABAM under the registration number CNMT-5423. In addition, flowers of $B$. verticillata with receptacles and stems were collected in three replicates and transported in thermal boxes to the Food Technology Laboratory, UFMT. Flowers were removed from the receptacle with tweezers and kept in a freezer until analysis of the volatiles by gas chromatography coupled with mass spectrometry (GC/MS).

Palynological analysis followed the methodology described by BARTH (1989), with polliniferous species (e.g., wind-pollinated like Cecropia sp.) counted separately (LOUVEAUX et al. 1978). Residues were used to assemble permanent slides that were cataloged and kept in the Pollen Reference Collection of the Paleontology Laboratory of UFMT, Cuiabá Campus.

Ten volunteer evaluators, older than 18 years old, were selected for sensory analysis based on the discriminative power and reproducibility of each individual for the identification of undesirable honey odors (PIANA et al.; 2004; KRUŽÍK et al., 2017).

The evaluators received three honeys with random codes from crop years 2015-2018, one of which was a control sample (a honey without an undesirable odor) and two of which had off-odors, and the intensity of the odor attributes was evaluated by using a numerical scale from very intense offodor ( 4 on the scale) to no odor ( 1 on the scale). The evaluators also described the odor (PIANA et al., 2004; INSTITUTO ADOLFO LUTZ, 2008).

Headspace solid-phase microextraction (HS-SPME) was performed with a commercial polydimethylsiloxane/divinylbenzene fiber $(65 \mu \mathrm{m}$, Supelco, Bellefonte, PA, USA). The fiber was exposed to the sample headspace in $20 \mathrm{~mL}$ vials for SPME with $1.0 \mathrm{~g}$ of honey sample in a saline solution $(\mathrm{KCl})$. The extraction was carried out at $40^{\circ} \mathrm{C}$ and $500 \mathrm{rpm}$ for $30 \mathrm{~min}$ with the fiber exposed in the headspace. Thermal desorption of the compounds was performed directly on the injector for $10 \mathrm{~min}$.

An Agilent gas chromatograph (GCMS 7890A/5975C) equipped with a VF-Wax MS capillary column $(30 \mathrm{~m} \times 0.25 \mathrm{~mm}$ internal diameter $\times 0.25 \mu \mathrm{m}$, Agilent J\&W, Santa Clara, CA, USA) was used for analysis of volatile compounds in the honeys 
Table 1 - Skatole contents and sensory panel scores for the off-odor attribute in Apis mellifera honey from some cities in the mid-north region of Mato Grosso State, Brazil.

\begin{tabular}{|c|c|c|c|c|c|}
\hline Honey & Apiary locality & Geographical coordinates & Haverst & Skatole (mg.kg $\left.{ }^{-1}\right)$ & Score $^{1}$ \\
\hline Control $^{2}$ & Santa Carmen & 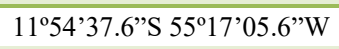 & 2016 & $\mathrm{ND}^{3}$ & $1.3 \mathrm{a}^{4}$ \\
\hline H1 & Nova Ubiratã & $13^{\circ} 36^{\prime} 53^{\prime \prime} \mathrm{S} 54^{\circ} 49^{\prime} 14^{\prime \prime} \mathrm{W}$ & 2015 & $\mathrm{NA}^{5}$ & $3.4 \mathrm{c}$ \\
\hline $\mathrm{H} 2$ & Sinop & $11^{\circ} 52^{\prime} 10.0^{\prime \prime S} 55^{\circ} 37^{\prime} 08.7^{\prime \prime W}$ & 2015 & NA & $3.6 \mathrm{c}$ \\
\hline H3 & Sinop & $11^{\circ} 52^{\prime} 10.0^{\prime \prime S} 55^{\circ} 37^{\prime} 08.7^{\prime \prime W}$ & 2016 & NA & $3.7 \mathrm{c}$ \\
\hline $\mathrm{H} 4$ & Tabaporã & $11^{\circ} 19^{\prime} 8^{\prime \prime} \mathrm{S} 56^{\circ} 14^{\prime} 56^{\prime \prime} \mathrm{W}$ & 2017 & ND & $1.6 \mathrm{a}$ \\
\hline H5 & Santa Carmen & $11^{\circ} 54^{\prime} 37.6^{\prime \prime S} 55^{\circ} 17^{\prime} 05.6^{\prime \prime} \mathrm{W}$ & 2017 & ND & $1.4 \mathrm{a}$ \\
\hline H6 & Sinop & $11^{\circ} 53^{\prime} 51^{\prime \prime S} 55^{\circ} 27^{\prime} 36^{\prime \prime} \mathrm{W}$ & 2017 & $0.484 \mathrm{~d}^{2}$ & $3.6 \mathrm{c}$ \\
\hline $\mathrm{H} 7$ & Sinop & $11^{\circ} 53^{\prime} 51^{\prime \prime S} 55^{\circ} 27^{\prime} 36^{\prime \prime} \mathrm{W}$ & 2018 & $0.425 \mathrm{~d}$ & $3.0 \mathrm{~b}$ \\
\hline $\mathrm{H} 8$ & Sinop & $11^{\circ} 51.683^{\prime} \mathrm{S} 55^{\circ} 34.406^{\prime} \mathrm{S}$ & 2018 & $0.328 \mathrm{c}$ & $3.7 \mathrm{c}$ \\
\hline H9 & Sinop & $12^{\circ} 08.874^{\prime}$ S $55^{\circ} 30.406^{\prime} \mathrm{W}$ & 2018 & $0.155 \mathrm{~b}$ & $2.8 \mathrm{~b}$ \\
\hline $\mathrm{H} 10$ & Ipiranga do Norte & $12^{\circ} 25^{\prime} 13^{\prime \prime S} 56^{\circ} 3$ '41" W & 2018 & $0.079 \mathrm{a}$ & $2.9 \mathrm{~b}$ \\
\hline
\end{tabular}

${ }^{1}$ Scores for the off-odor attribute from 1 to 4 , i.e. from no off-odor to very intense.

${ }^{2}$ Control honey free from off-odor.

${ }^{3} \mathrm{ND}=$ Not detected.

${ }^{4}$ Averages followed by the same letter in the columns do not differ significantly from each other (Scott-Knott test $\left.\mathrm{p}>0.05\right)$.

${ }^{5} \mathrm{NA}=$ Not analyzed.

and the flowers of $B$. verticillata. Ultrapure helium at $0.8 \mathrm{~mL} \mathrm{~min}^{-1}$ was used as the carrier gas. The injector temperature was set at $250{ }^{\circ} \mathrm{C}$, and the temperature of the ion source was $230{ }^{\circ} \mathrm{C}$ with an electron energy of $70 \mathrm{eV}$. The oven temperature program was: $45^{\circ} \mathrm{C}$ (held for $2 \mathrm{~min}$ ), $40{ }^{\circ} \mathrm{C} \mathrm{min}^{-1}$ to $300{ }^{\circ} \mathrm{C}$ (held for 3 min). Identifications of compounds were performed by comparing the mass spectra obtained with the NIST Mass Spectral Search program, version 2.0, 2011. The skatole measurement was performed for samples H4-H10 with a 98\% purity standard (SigmaAldrich, St. Louis), by using a calibration curve of 0.01 to $0.6 \mathrm{mg} \mathrm{kg}^{-1}$ (BIANCHIN et al., 2014).

The experimental design was completely randomized and the averages of the scores were compared with the Scott-Knott test $(\mathrm{p}>0.05)$.

\section{RESULTS AND DISCUSSION}

We reported pollen from Borreria verticillata (L.) G. Mey (Rubiaceae - Rubioideae Spermacoceae) in all ten of the honey samples that were analyzed. In samples $\mathrm{H} 1-\mathrm{H} 4, \mathrm{H} 7$, and $\mathrm{H} 9$, this pollen type was predominant, and the honeys were classified as monofloral; in samples H5, H6, H8, and $\mathrm{H} 10, B$. verticillata pollen was accessory, with a percentage in the range of 16-45\% (BARTH, 1989; RAMÍREZ-ARRIAGA, et al., 2011).

$B$. verticillata is a nectariferous plant (BARTH, 2004; MAIA-SILVA et al., 2012), and its monofloral honey has been classified as being of low quality because of its sensorial attributes (BARTH, 1998). ALMEIDA-MURADIAN et al. (2014) described the odor of a bifloral honey of $B$. verticillata and Hyptis (Lamiaceae) in the following terms: "animal, resin, wax, fruit, malt, coffee, caramel, wood, and smoke smells", i.e., a mixture of pleasant and unpleasant odors.

The honeys investigated herein contained skatole, except samples H4 and H5 (Table 1). The prior volatilization of the skatole of samples H4 and $\mathrm{H} 5$ is a possibility, because the beekeepers only delivered the honey from the harvest of 2017 in February of 2018 and they confirmed that the products had been stored in plastic buckets at room temperature (BURDOCK, 2010).

The monofloral honeys $\mathrm{H} 1, \mathrm{H} 2$, and $\mathrm{H} 3$ were classified as having intense to very intense off-odors (Table 1); although the scores for H6 and $\mathrm{H} 8$ were similar despite the fact that $B$. verticillata pollen was accessory. Meanwhile, for $\mathrm{H} 7, \mathrm{H} 9$, and H10, average scores of 2.9 were given, with no significant difference between them, even though $B$. verticillata pollen was dominant in $\mathrm{H} 7$ and $\mathrm{H} 9$ but was accessory pollen in H10. Therefore, the off-odor honey contained $B$. verticillata pollen, but there is no quantitative correlation between the frequency of this pollen and the odor attributes.

Samples H6 and H7 presented the highest contents of skatole, followed by $\mathrm{H} 8$, and these honeys 
were classified as having intense to very intense offodors (Table 1). Samples H1-H3 showed similar odor classification and, as shown in table 2, exhibited the largest average percentages for the relative area of skatole $(10.2 \% \pm 2.3 \%)$ in comparison with those of the other honeys investigated $(3.5 \% \pm 2.8 \%)$. Skatole was not identified in the volatile compound profiles of the control honey (without an unpleasant odor); skatole was also not detected in the H4 and H5 honeys, and their scores for unpleasant odor attributes did not differ from that of the control honey (Table 1, Figure 1). These results suggested that skatole contributed to the off-odor characteristics of the product.

In the off-odor honey descriptions, evaluators reported an "animal feces smell", "pigsty odor", and "smell of swine feces"; these odor descriptions can be explained by the presence of skatole in the volatile profile, because this compound presents a fecal odor (SIEFARTH \& BUETTNER, 2014; MAHMOUD \& BUETTNER, 2016).

The major volatile compounds in $B$. verticillata flowers were toluene, linalool, and benzaldehyde with relative abundances of $17.5 \%$, $15.1 \%$, and $7.2 \%$, respectively. Styrene was transferred from the flowers of $B$. verticillata to the honeys, with the exception of H9 (Tables 2 and 3). Benzaldehyde was observed in the flowers and in samples H1-H4, H6, and $\mathrm{H} 10$, whereas toluene was only transferred from the flowers of B. verticillata to samples $\mathrm{H} 1-\mathrm{H} 3$ (Tables 2 and 3). However, there was no transfer of skatole, possibly because this substance originated from the metabolic processes of bees or from microorganisms associated with bees or with $B$. verticillata (BARONI et al., 2006; NAEF et al., 2004; RIBEIRO et al., 2008).

Table 2 - Relative abundance in percentages of major volatile compounds identified in Borreria verticillata flowers and in off-odor honey from 2015 to 2017 harvests in mid-northern region of Mato Grosso state, Brazil.

\begin{tabular}{|c|c|c|c|c|c|c|}
\hline Compound & Flower $^{1}$ & $\mathrm{H}^{2}$ & $\mathrm{H} 2$ & $\mathrm{H} 3$ & $\mathrm{H} 4$ & H5 \\
\hline Toluene & $17.5 \pm 3.5^{3}$ & $16.0 \pm 4.3$ & $17.5 \pm 3.5$ & $18.3 \pm 5.1$ & - & - \\
\hline Ethylbenzene & - & $3.2 \pm 0.7$ & $4.9 \pm 1.1$ & $2.6 \pm 0.8$ & - & - \\
\hline 5-methyl-hexanone & - & - & $2.3 \pm 0.3$ & - & - & - \\
\hline Styrene & $3.6 \pm 1.0$ & $6.9 \pm 1.9$ & $7.8 \pm 1.8$ & $8.9 \pm 2.4$ & $1.4 \pm 0.1$ & $1.9 \pm 0.4$ \\
\hline Rose oxide (cis) & $6.1 \pm 2.1$ & - & - & - & - & - \\
\hline 1-Octen-3-ol & $5.2 \pm 1,3$ & - & - & - & - & - \\
\hline Tethramethybenzene & - & $1.0 \pm 0.5$ & - & - & - & $1.3 \pm 0.2$ \\
\hline Benzaldehyde & $7.2 \pm 0.9$ & $4.1 \pm 1.3$ & $5.1 \pm 1.2$ & $2.7 \pm 0.3$ & $1.3 \pm 0.2$ & - \\
\hline Salicylic acid & $6.0 \pm 2.1$ & - & - & - & - & - \\
\hline D-Linonene & - & $2.0 \pm 0.7$ & - & - & - & - \\
\hline Cyclotetrasiloxane & - & $1.4 \pm 0.2$ & - & - & - & $0.3 \pm 0.0$ \\
\hline Gamma-Terpinene & - & - & - & $1.3 \pm 0.2$ & - & - \\
\hline Tetrasiloxane & - & - & - & - & - & - \\
\hline Linalool & $15.1 \pm 3.9$ & - & - & - & - & - \\
\hline Hotrienol & - & - & $2.3 \pm 0.4$ & $2.9 \pm 0.5$ & - & - \\
\hline Linalool oxide & - & - & - & $1.0 \pm 0.1$ & - & $5.4 \pm 1.2$ \\
\hline$\Delta^{3}$-Carene & - & $3.0 \pm 0.4$ & - & - & - & $3.0 \pm 0.8$ \\
\hline Benzoic acid & - & $3.4 \pm 1.2$ & - & - & - & $4.7 \pm 1.3$ \\
\hline Benzeneacetaldehyde & - & - & $4.3 \pm 1.2$ & $3.6 \pm 0.1$ & $3.2 \pm 0.2$ & - \\
\hline Benzeneacetic acid & - & $3.3 \pm 0.6$ & - & - & - & $32.7 \pm 5.3$ \\
\hline Pentanoic acid & - & $4.3 \pm 1.5$ & $5.5 \pm 1.9$ & $7.0 \pm 2.1$ & - & - \\
\hline Cyclohexasiloxane & - & - & - & - & - & $1.4 \pm 0.4$ \\
\hline Neroloxide & - & - & - & $2.0 \pm 0.7$ & $5.8 \pm 1.2$ & - \\
\hline Skatole & - & $11.3 \pm 4.2$ & $10.0 \pm 3.2$ & $9.8 \pm 3.1$ & - & - \\
\hline Benzeneacetic acid & - & - & $6.3 \pm 1.8$ & $3.0 \pm 1.1$ & $2.4 \pm 0.4$ & - \\
\hline Cyclohexasiloxane & - & $1.03 \pm 0.4$ & - & - & $1.6 \pm 0.1$ & - \\
\hline Benzenepropanoic acid & - & - & - & - & $1.5 \pm 0.2$ & $11.5 \pm 4.3$ \\
\hline
\end{tabular}

${ }^{1}$ Flower of $B$. verticilata.

${ }^{2}$ Off-odor honey samples (H1 to H5). H1 and H2; H3; H4 and H5, respectively from 2015; 2016 and 2017 harvests.

${ }^{3}$ Average relative abundance \pm standard deviation. 


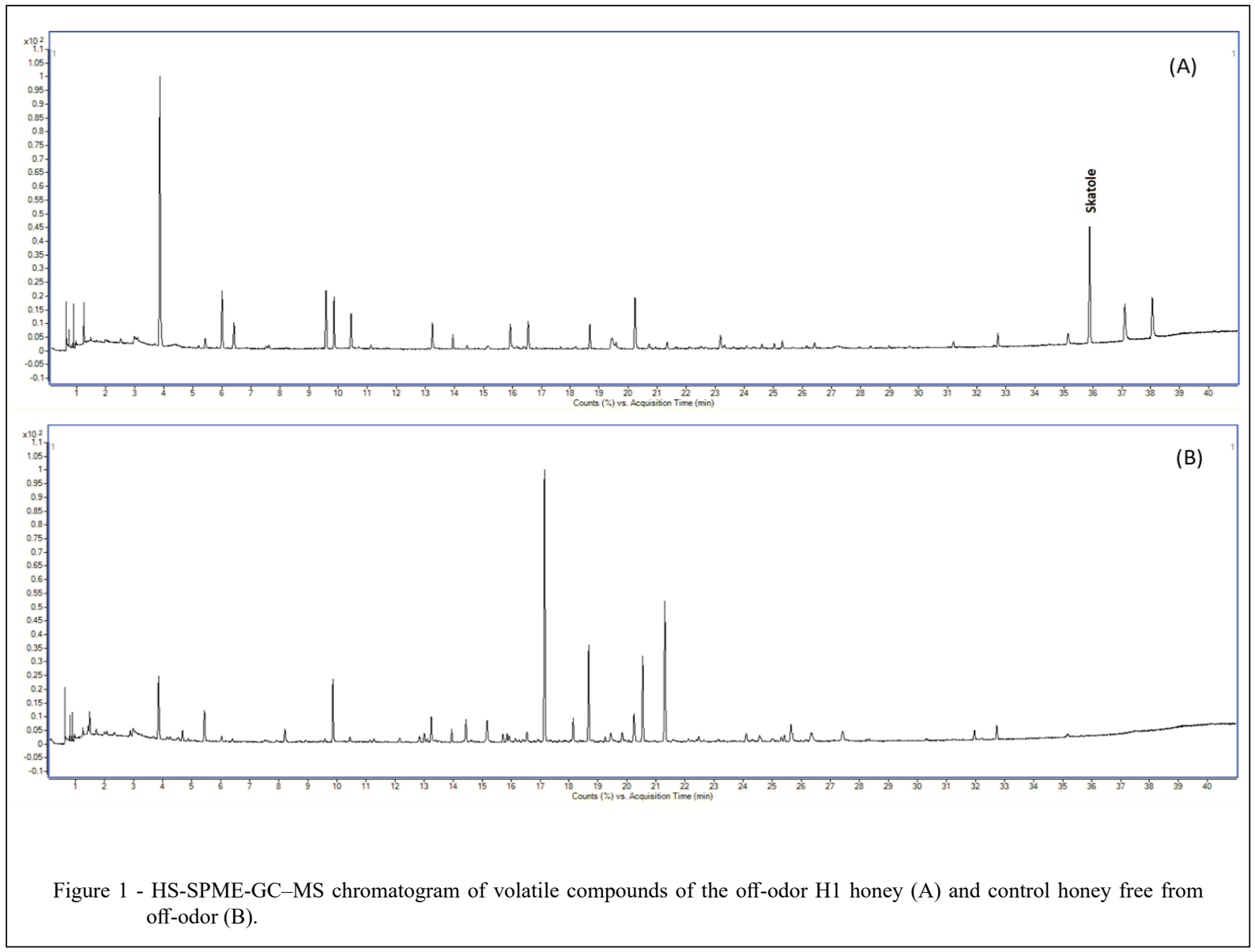

Table 3 - Relative abundance percent of major volatile compounds identified in off-odor honey (H6 to H10) from 2018 harvest in midnorthern region of Mato Grosso State, Brazil.

\begin{tabular}{|c|c|c|c|c|c|}
\hline Compound & H6 & $\mathrm{H} 7$ & $\mathrm{H} 8$ & H9 & H10 \\
\hline Ethylbenzene & $6.3 \pm 1.4^{1}$ & $4.1 \pm 1.7$ & $10.67 \pm 2.6$ & - & $2.8 \pm 0.2$ \\
\hline 5-methyl-hexanone & - & - & - & - & - \\
\hline Styrene & $21.9 \pm 4.6$ & $15.6 \pm 4.0$ & $13.01 \pm 1.5$ & - & $5.3 \pm 1.4$ \\
\hline Tethramethybenzene & - & $1.4 \pm 0.2$ & - & - & $1.9 \pm 0.1$ \\
\hline Benzaldehyde & - & - & $2.25 \pm 0.5$ & - & - \\
\hline D-Linonene & - & $2.6 \pm 0.6$ & - & $20.2 \pm 4.3$ & $49.0 \pm 3.5$ \\
\hline Cyclotetrasiloxane & - & - & $2.64 \pm 1.1$ & $1.1 \pm 0.1$ & - \\
\hline Gamma-Terpinene & $1.2 \pm 0.2$ & $1.3 \pm 0.3$ & - & $1.6 \pm 0.3$ & - \\
\hline Tetrasiloxane & - & - & $1.39 \pm 0.4$ & - & - \\
\hline Hotrienol & $4.4 \pm 1.3$ & $12.9 \pm 3.1$ & - & - & - \\
\hline Benzoic acid & $1.5 \pm 0.1$ & $1.7 \pm 0.2$ & - & $2.5 \pm 0.3$ & - \\
\hline Benzeneacetaldehyde & - & - & - & - & - \\
\hline Benzeneacetic acid & $14.4 \pm 3.9$ & $18.4 \pm 4.3$ & $6.3 \pm 0.7$ & $17.1 \pm 3.7$ & $2.7 \pm 0.4$ \\
\hline Cyclohexasiloxane & $1.4 \pm 0.3$ & $2.8 \pm 0.3$ & - & $2,1 \pm 0.6$ & $2.4 \pm 0.5$ \\
\hline Neroloxide & - & - & - & - & - \\
\hline Skatole & $5.2 \pm 0.8$ & $3.9 \pm 0.2$ & $6.0 \pm 2.1$ & $0.2 \pm 0.0$ & $2.6 \pm 0.8$ \\
\hline Benzenepropanoic acid & $9.5 \pm 1.9$ & $6.8 \pm 1.5$ & $3.4 \pm 0.4$ & $5.1 \pm 1.7$ & - \\
\hline
\end{tabular}

${ }^{1}$ Average relative abundance percent \pm standard deviation.

Ciência Rural, v.51, n.7, 2021. 
There are no reports of the presence of skatole in honey from Brazil or other countries (BARONI et al., 2006; DE MARIA \& MOREIRA, 2003; KRUŽ́́K et al., 2017; PATRIGNANI et al., 2018), but it has been described in off-flavor meat products.

In swine, skatole is one of the compounds associated with male odor, because it is a product of the degradation of tryptophan by lactic bacteria of the intestinal colon (CLAUS et al, 1994). There are no scientific reports of the amino acid profile of $B$. verticillata honey, but the high protein level $(2,236$ $\mu \mathrm{g} \mathrm{g}^{-1}$ ) of this honey stands out relative to those Sapindaceae, eucalyptus, and citrus honeys, which have protein contents of 1,203, 734, and $628 \mu \mathrm{g} \mathrm{g}^{-1}$, respectively (AZEREDO et al., 2003).

In addition, skatole has been identified among off-flavor compounds in trout (Oncorhynchus mykiss) and Gibel carp (MAHMOUD \& BUETTNER, 2016). However, there is no consensus for the origin of skatole in fish, and it was hypothesized that the river had been contaminated with swine feces. In this study, the hypothesis of bees collecting in a pigsty is unlikely, because there were no rural constructions within a radius of $3 \mathrm{~km}$ of the apiary investigated (BRASIL, 1985).

\section{CONCLUSION}

The off-odor honeys investigated contained Borreria verticillata (L.) G. Mey pollen. Six samples (H1-H4, H7, and H9) were monofloral honeys, whereas $B$. verticillata pollen was only one of the components in four others (H5, H6, $\mathrm{H} 8$, and H10). However, we did not observe a relationship between the $B$. verticillata pollen abundance and the odor characteristics of the honeys investigated.

Skatole was quantified and/or identified in honeys categorized as having an intense offodor. However, further studies are required to investigate the origin of the skatole because it was not transferred directly from $B$. vercillata flowers to the honey.

\section{ACKNOWLEDGMENTS}

Carlos D'Apolito thanks "Conselho Nacional de Desenvolvimento Científico e Tecnológico" (CNPq) and "Fundação de Amparo à Pesquisa do Estado de Mato Grosso" (FAPEMAT) [DCR grant number 568838/2017]. Carmen Wobeto thanks Professor Silane Aparecida Ferreira da Silva Caminha for helping in palynological analyses and Exp. Jefferson Luiz Banderó for the first honey collection. This research was financed in part by the Coordenação de Aperfeiçoamento de Pessoal de Nível Superior (CAPES), Brasil - Finance code 001.

\section{BIOETHICS AND COMMITTEE APPROVAL}

BIOSECURITY

The sensory analysis of this study was approved by the Júlio Müller Hospital Ethics Committee, Federal University of Mato Grosso (CAAE: 44328315.2.0000.5541, 06/26/2015), according to Resolution 466/2012 of the Ministry of Health that establishes the guidelines and rules regulating research involving human beings.

\section{DECLARATION OF CONFLICT OF INTEREST}

The authors declare no conflict of interest. The founding sponsors had no role in the design of the study; in the collection, analyses, or interpretation of data; in the writing of the manuscript, and in the decision to publish the results.

\section{AUTHOR'S CONTRIBUTIONS}

BRF and SCCB performed cromatography analyses; CD performed pollen analyses; LCS performed botanical identifications; EAA performed statistical analyses; $\mathrm{CW}$ designed the research, coordinated the project, performed sensory analyses and wrote the manuscript. All authors were involved in writing and revision of the final draft.

\section{REFERENCES}

ALMEIDA-MURADIAN, L. B. et al. Preliminary data on brazilian monofloral honey from the northeast region using FT-IR ATR spectroscopic, palynological, and color analysis. Química Nova, v.37, n.4, p.716-719, 2014. Available from: <http://www. scielo.br/pdf/qn/v37n4/22.pdf $>$. Accessed: Jul. 11, 2018. doi: 10.5935/0100-4042.20140115.

AZEREDO, L. da C. et al. Protein contents and physicochemical properties in honey samples of Apis mellifera of different floral origins. Food Chemistry, v.80, n.2, p.249-254, 2003. Available from: $\quad<\mathrm{http} / / \quad$ www.sciencedirect.com/science/article/pii/ S0308814602002613?via\%3Dihub>. Accessed: Jul. 15, 2017. doi: 10.1016/S0308-8146(02)00261-3.

BARONI, M. V. et al. Determination of Volatile Organic Compound Patterns Characteristic of Five Unifloral Honey by Solid-Phase Microextraction-Gas Chromatography-Mass Spectrometry Coupled to Chemometrics. Journal of Agricultural and Food Chemistry, v.54, p.7235-7241, 2006. Available from: <https://pubs.acs.org/doi/10.1021/ jf061080>. Accessed: Jul. 18, 2017. doi: 10.1021/jf061080e.

BARTH, O. M. O Pólen no mel brasileiro. Rio de Janeiro: Editora Luxor, 1989, 151p.

BARTH, O. M. Melissopalynology in Brazil: a review of pollen analysis of honeys, propolis and pollen loads of bees. Scientia Agricola, v.61, n.3, p:342-350, 2004. Available from: <https:// www.scielo.br/pdf/sa/v61n3/a18v61n3.pdf $>$. Accessed: Aug. 20, 2017. doi: 10.1590/S0103-90162004000300018.

BIANCHIN, J. N. et al. Screening of volatile compounds in honey using a new sampling strategy combining multiple extraction temperatures in a single assay by HS-SPME-GC-MS. Food Chemistry, v.145, n.15, p.1061-1065, 2014. Avalilable from: $\quad<$ https://www.sciencedirect.com/science/article/abs/pii/ 
S0308814613012776?via\%3Dihub>. Accessed: Jul. 2, 2017. doi: 10.1016/j.foodchem.2013.08.139

BURDOCK, G. A. Fenaroli's Handbook of Flavor Ingredients, 6 th. CRC Press, Taylor and Francis Group, Boca Raton, FL, 2010, 2136 p.

BRASIL. Ministério da Agricultura, Pecuária e Abastecimento. Portaria $n^{\circ} 6$ de 2 de julho de 1985. Aprova as Normas Higiênico Sanitárias e Tecnológicas para Mel, Cera de Abelhas e Derivados. Diário Oficial da União, Brasília, DF, 25 de julho de 1985, 1985.

CASTRO-VÁZQUEZ, L. et al. Changes in the volatile fractions and sensory properties of heather honey during storage under different temperatures. European Food Research and Technology, v.235, n.2, p.185-193, 2012. Available from: <https://link.springer.com/ article/10.1007/s00217-012-1756-1>. Accessed: Mar. 24, 2018 doi: $10.1007 / \mathrm{s} 00217-012-1756-1$.

CLAUS, R., et al. Physiological aspects of androstenone and skatole formation in the hoar: a review. Meat Science, v.38, p.289-305, 1994. Available from: <https://doi.org/10.1016/0309-1740(94)90118-X>. Accessed: Mar. 25, 2018. doi: 10.1016/0309-1740(94)90118-X.

DE MARIA, C. A. B.; MOREIRA, R. F. A. Compostos voláteis em méis florais. Química Nova, 26(1):90-96, 2003. Available from: $<$ https://www.scielo.br/scielo.php?script $=$ sci_arttext\&pid=S010040422003000100016\&lng=pt\&nrm=iso\&tlng=pt $>$. Accessed: Mar. 24, 2018. doi: 10.1590/S0100-40422003000100016.

DE-MELO, A. A. M. et al. Composition and properties of Apis mellifera honey: A review. Journal of Apicultural Research, v.57, n.1, p.5-37, 2018. Available from: <https://www.tandfonline. com/doi/full/10.1080/00218839.2017.1338444>. Accessed: Mar. 24, 2019. doi: 10.1080/00218839.2017.1338444.

INSTITUTO ADOLFO LUTZ. Métodos físico-químicos para análise de alimentos - 4a. Ed. 1a. Edição Digital. São Paulo: Instituto Adolfo Lutz, p.1020. 2008. Available from: <http:// www.ial.sp.gov.br/resources/editorinplace/ial/2016 3 19/ analisedealimentosial_2008.pdf $>$. Accessed: Oct. 22, 2015.

IBGE. Instituto brasileiro de geografia e estatística. Produção da Pecuária Municipal, 2010. Volume 38. Rio de Janeiro: IBGE. Available from: <https://biblioteca.ibge.gov.br/visualizacao/ periodicos/84/ppm_2010_v38_br.pdf $>$. Accessed: Aug. 12, 2017.

IBGE. Instituto brasileiro de geografia e estatística. Produção da Pecuária Municipal, 2011. Volume 39. Rio de Janeiro: IBGE. Available from: <https://biblioteca.ibge.gov.br/visualizacao/ periodicos/84/ppm_2011_v39_br.pdf $>$. Accessed: Aug. 12, 2017.

IBGE. Instituto brasileiro de geografia e estatística. Produção da Pecuária Municipal, 2012. Volume 40. Rio de Janeiro: IBGE. Available from: <https://biblioteca.ibge.gov.br/visualizacao/ periodicos/84/ppm_2012_v40_br.pdf>. Accessed: Aug. 12, 2017.

IMEA. Instituto Mato-Grossense de Economia Agropecuária. Mapa das macrorregiões do IMEA. Mato Grosso/Brasil, novembro de 2017. Available from: <http://www.imea.com.br/upload/publicacoes/ arquivos/justificativamapa.pdf $>$. Accessed: Jan. 25, 2018.

KRUŽÍK, V. et al. Study on honey quality evaluation and detection of adulteration by analysis of volatile compounds. Journal of Apicultural Science, v.61 n.1, p.17-27, 2017. Available from: $<$ https://doi.org/10.1515/jas-2017-0002>. Accessed: Jan. 15, 2018. doi: $10.1515 /$ jas-2017-0002.
LOUVEAUX, J., MAURIZIO, A., VORWOHL, G. (1978) Methods of Melissopalynology, Bee World, 59:4, 139-157. Avalilable from: $<$ https://doi.org/10.1080/0005772X.1978.11097714>. Accessed: Jan. 25, 2018. doi: 10.1080/0005772X.1978.11097714.

MAHMOUD, M. A.; BUETTNER, A. Characterization of aroma-active and off-odour compounds in German rainbow trout (Oncorhynchus mykiss). Part I: Case of aquaculture water from earthen-ponds farming. Food Chemistry, v.210, p.623-630, 2016. Available from: <https://www.sciencedirect.com/science/article/abs/ pii/S0308814616307087?via\%3Dihub>. Accessed: Jan. 15, 2018. doi: 10.1016/j.foodchem.2016.05.030.

MAIA-SILVA, C.; et al. Guia de plantas: Visitadas por abelhas na Caatinga, $\left(1^{\text {st }}\right.$ ed). Fortaleza: Fundação Brasil Cidadão, 2012. Available from: <https://www.mma.gov.br/estruturas/203/ arquivos/livro_203.pdf>. Accessed: Jan. 15, 2018.

NAEF, R. et al. From the linden flower to linden honey - volatile constituents of linden nectar, the extract of bee-stomach and ripe honey. Chemistry \& Biodiversity, v.1, p.1870-1879, 2004. Available from: $<$ https://onlinelibrary.wiley.com/doi/abs/10.1002/cbdv.200490143>. Accessed: Jul. 10, 2018. doi: 10.1002/cbdv.200490143.

PATRIGNANI, A. M. et al. Volatile compounds of Argentinean honeys: Correlation with floral and geographical origin. Food Chemistry, v.246, p.32-40, 2018. Available from: <https://www.sciencedirect. com/science/article/abs/pii/S0308814617318125?via\%3Dihub>. Accessed: Jan. 10, 2019. doi: 10.1016/j.foodchem.2017.11.010.

PIANA, M. L. et al. Sensory analysis applied to honey: state of the art. Apidologie, v.35, p.S26-S37, 2004. Available from: <https:// www.apidologie.org/articles/apido/abs/2004/06/MHS05/MHS05. html>. Accessed: Jan. 10, 2019. doi: 10.1051/apido:2004048.

RAMÍREZ-ARRIAGA, E. et al. Botanical characterization of Mexican honeys from a subtropical region (Oaxaca) based on pollen analysis. Grana, v.50, v.1, p.40-54, 2011. Available from: $<$ https:// www.tandfonline.com/doi/full/10.1080/00173134.2010.537767> . Accessed: Jan. 10, 2019. doi: 10.1080/00173134.2010.537767.

RIBEIRO, M. C.; et al. Volatile profile of the headspace fraction of "assa-peixe" (Vernonia sp.) honeys. Food Science and Technology, v.28, n.1, p.169-171, 2008. Available from: $<$ http://www.scielo.br/pdf/cta/v28n1/23.pdf $>$. Accessed: Jan. $10,2019$.

RIBEIRO, R. de O. R. et al. Influence of the time/temperature binomial on the hydroxymethylfurfural content of floral honeys subjected to heat treatment. Ciência e Agrotecnologia, v.36, n.2, p.204-209, 2012. Available from: <http://www.scielo.br/pdf/cagro/ v36n2/09.pdf $>$. Accessed: Jan. 20, 2019.

SEISONEN, S., et al. Characterization of the aroma profiles of different honeys and corresponding flowers using solid-phase microextraction and gas chromatography-mass spectrometry/ olfactometry. Food Chemistry, v.169, p.34 40, 2015. Available from: <https://www.sciencedirect.com/science/article/abs/pii/ S030881461401173X?via\%3Dihub>. Accessed: Jan. 25, 2019. doi: 10.1016/j.foodchem.2014.07.125.

SIEFARTH, C.; BUETTNER, A. The aroma of goat milk: seasonal effects and changes through heat treatment. Journal of Agricultural and Food Chemistry, v.62, n.49, p.11805-11817. 2014. Available from: <https://pubs.acs.org/doi/10.1021/ jf5040724>. Accessed: Mar. 25, 2019. doi: 10.1021/jf5040724. 